\title{
The Meaning Crisis of Curriculum in Information Age
}

\author{
Burhan Akpinar, Veli Batd1, Ender Özeren, and Gamze Kirilmazkaya
}

\begin{abstract}
Curriculum is a rather ambiguous term because of its nature. This ambiguousness has become even more severe due to reflections of paradigms of Information Age and its dominant phenomenon Information and Communication Technologies (ICT) on education.

The purpose of this study is to determine what meanings teachers attribute to curriculum, and then to assess these meanings within the literature. The study was carried out on 35 teachers in Elazig city center, Turkey. The study is a qualitative research, and the data were collected via open-ended interview forms. These data were then analyzed with content analysis and descrriptive statistical techniques. At the end of the study, it was revealed that the meanings the teachers attributed to curriculum are rather traditional, various and far from being integrity. From this, in can be said that curriculum in teachers' mind is shadowy. From a traditional perspective, this case may give birth to some problems during education process. However, this shadowy perception of teachers can turn into an advantage during the process in Information Age. Because, the teachers cannot be expected to be loyal to curriculum which they cannot make sense of. So, they can take some socio-psychological factors into consideration which curriculum do not foresee. Such an environment, in which effect of curriculum lessens for per students, is more humane, and it helps them to stay as themselves allowing them to form their own knowledge.
\end{abstract}

Index Terms-Meaning crisis of curriculum, curriculum, meaning of curriculum, information age program.

\section{INTRODUCTION}

Curriculum is one of the topics that are discussed a lot in education system. Because, as a discipline, it is hard, fragmentary and complex. According to Pinar [1], "period of curriculum development has ended. In fact, it is not easy to say that the curriculum which Bobbitt developed and then Taba and Tyler formulated is the same as the one in present. Regarding this, Longstreet and Shane's opinions that "Curriculum is a historical accident" is interesting. According to Marsh [2], curriculum is a kind of reaction against meeting educational approaches that are increasingly getting more complex . About this issue, John Watson's views about Dewey, who is effective in present day's curriculum design, is very striking: "I never knew about what he was talking, and I still do not know". Hofstadter added to this: "He wrote a prose in

Manuscript received September 28, 2016; revised October 31, 2016 Burhan Akpinar is with the Firat University, Dept. of Education, Elazig, Turkey (e-mail: bakpinar23@gmail.com).

Veli Batdı is with the Kilis Yedi Aralık University, Dept. of Education, Kilis, Turkey (e-mail: veb_27@hotmail.com).

Ender Özeren is with the Dicle University, Çermik Vocational High School, Diyarbakir, Turkey (e-mail: enderozeren@gmail.com).

Gamze Kirilmazkaya is with the Harran University, Dept. of Education, Şanliurfa, Turkey (e-mail: gamzekirilmazkaya@ gmail.com). terrible uncertainty and flexibility." [3].

A recent approach in education, which is "focusing on process rather than results" have distorted the meaning of curriculum too. Because, focusing on the process more than needed makes curriculum synonymous with education. Pinar's this view on the meaning crisis of curriculum is remarkable: "Curriculum theory is a complex, sometimes cacophonous, chorus, "the sound of silence breaking".

Additionally, Information age and its dominant phenomenon Information-Communication Technologies have deepened the meaning crisis of curriculum making education independent from time and place constraints. Because, curriculum has traditionally time-context and various standards. However, Information age curriculum is not standard [4]. ICT makes curriculum closer to postmodernism which is a paradigm of Information Age. Even the information concept of postmodernism alone, which refuses any kind of exact results, goals and standards, has potential to lead to a deep meaning crisis in traditional meaning of curriculum. Because, postmodern educational theory means a radical break from what we are used to in education [5]. In such a case, from a positivist perspective, which is substantially traditional, postmodern curriculum is an ideological rather than a scientific idea. Because, in positivism, ideology is anything that is not scientific [6]. However, despite all these discussions, curriculum is still seen as an indispensable component of education, especially for countries which are on the border of Information Age, and have not gone out of Industrial Age like Turkey. In the statement by Covey [7], Turkey is running its schools and, of course its curricula according to Industrial Age in a world living Information Age.

Another reason for the vagueness of curriculum is the period it is dealt and its philosophy. Because, curriculum is affected by political, social, scientific and technological developments and changes. Curriculum can also differ in the way it handles human, its epistemological approach, and school type and level [8]. Anyon [9] adds archiving issues; and Clement [10] adds thoughts and beliefs of the society to this list. When we add human and information paradigms of Information Age to that list, the meaning of curriculum gets even more complex. Therefore, there are several definitions of curriculum in literature [11].

The fact that curriculum is so ambiguous in terms of meaning, definition and content has the potential to lead to a crisis in practice. Because, it is debatable that teachers can apply an official document (curriculum) which they cannot make sense of. In order to clarify this debate, it is important to determine the problems about this in practice. At this point, this study, whose purpose is to determine teachers' views about the meaning crisis of curriculum, can contribute to the literature. 


\section{METHOD}

\section{A. Model of the Study}

The study is a qualitative research, and it was conducted using survey model. Qualitative researches are researches in which perceptions and cases are described in their natural environments realistically and wholly using such qualitative data collection tools as interview forms [12]. As to the survey model, it is a research approach whose aim is to describe a case in past or present as is it is [13].

\section{B. Working Group}

The study was carried out with total 35 teachers working in official schoosl in Elazig city center in 2015-2016 academic year. The group was determined with purposeful sampling method. In this type of sampling method, the researcher uses his/her own judgment as who will be chosen for the study, and chooses the appropriate group [14]. Demographic information about the participants are as follows: Woman $(\mathrm{n}=13 ; \% 37,1)$; Men $(\mathrm{n}=22 ; 62,9)$. Working year: $1-5$ years $(\mathrm{n}=10 ; \% 28,6), 6-10$ years $(\mathrm{n}=11 ; \% 31,4), 11-15$ years $(\mathrm{n}=5 ; \% 14,3), 16-20$ years $(\mathrm{n}=6 ; \% 17,1), 21$ years and over $(\mathrm{n}=3 ; \% 8,6)$. Branches: Classroom teacher $(\mathrm{n}=13, \% 37,14)$, Turkish teacher $(n=5, \% 14,29)$, Mathematics teacher $(\mathrm{n}=4, \% 11,43)$, Social Sciences teacher $(\mathrm{n}=6, \% 17,14)$, Gym teacher $(n=2, \% 5,7)$, and Pre-school teacher $(n=5 ; \% 14,29)$.

\section{Data Collection and Their Analysis}

The data were collected via interview forms which are suitable [15], [16] for qualitative researches. The interview forms consists of total five questions of whose three are about demographics questions and the rest two are about curriculum. These forms were applied to the working group by the researchers. In order to analyze the data, content analysis was used, and descriptive statistical techniques were also employed as a supportive way. Content analysis is the process of digitizing what people say or write according to clear instructions [14]. In order to clarify the analysis of qualitative findings or to increase the reliability, quantitative techniques can be employed [12]. In the study, direct quotations were also used as a supportive way.

\section{FINDINGS AND THEIR INTERPRETATION}

\section{A. The Meaning of Curriculum}

The meaning of curriculum is related to its philosophical, historical, personal, social and economic bases etc. These bases form the outer boundaries of curriculum [1]. The answers that the participants gave to the question "What do you understand from curriculum?" were gathered under certain titles and then they are presented in Table I.

When this table is examined, meaning crisis of curriculum is seen very clearly. Because all these answers are about only just one dimension of curriculum, rather than whole of it. Therefore, it can be claimed that the teachers do not know outer boundaries of curriculum, accordingly the whole curriculum.

The participants see curriculum as "a plan to transfer information" ( $n=11)$; "course content" ( $n=9)$; "a way to reach the goals" ( $n=3)$ and "constructivist education" $(n=3)$. So, it can be said that teachers have a traditional and essential understanding of curriculum. Their these views also support this: P-24: "Curriculum is the content that a teachers plans". P-11: "Curriculum is improvizations in course content." P-5: "Curriculum is a plan of what will be done during the year." The terms like "guide", "plan", "content" and "way" that the participants used evokes early-period curriculum. Likewise, in a study by Aykac and Celik [17], it was revealed that teachers liken curriculum to "a system". Even though Turkey has been using a Progressive and Constructivist curriculum [18], which is as contemporary, curriculum is teachers' mind is still traditional. This case may bring Turkey's reform in 2005 into disrepute. Because, there is relationship between the failure of education systems and teachers' perceptions [17].

TABLE I: MEANING OF CURRICULUM

\begin{tabular}{ll} 
What do you understand from curriculum? & f \\
\hline $\begin{array}{l}\text { A plan and a guide to transfer information } \\
\text { A document showing course contents }\end{array}$ & 9 \\
A general way to reach the goals & 3 \\
$\begin{array}{l}\text { Constructivist education } \\
\text { Practices in a year }\end{array}$ & 3 \\
$\begin{array}{l}\text { Teaching according to a plan } \\
\text { Method, technique, assessment and evaluation }\end{array}$ & 1 \\
$\begin{array}{l}\text { Constructivist education } \\
\text { A written source that top executives send as what to } \\
\text { do in the class }\end{array}$ & 1 \\
\hline
\end{tabular}

These limited expressions of the teachers about curriculum can indicate that they are not aware of inner boundaries of curriculum. In similar studies [19]-[21], the results show that the problem is general.

\section{B. Analogies for Curriculum}

Another way of determining what meaning teachers attribute to curriculum is using analogies. Teachers' analogies related to curriculum can be seen as a clue of their perceptions about it. The answers that teachers gave to the question "What do you liken curriculum to?" were gathered under some titles and they are presented in Table II.

\begin{tabular}{ll}
\multicolumn{2}{c}{ TABLE II: ANALOGIES FOR CURRICULUM } \\
\hline Answers & f \\
\hline Planned activities & 6 \\
Travelling, traffic, a ship moving to its aims & 4 \\
Ignition or an engine of a vehicle & 2 \\
Compass, route map & 2 \\
Recipe & 2 \\
A human life & 2 \\
Team, a basket team & 2 \\
Prescription & 2 \\
Shopping list & 2 \\
\hline
\end{tabular}


Analogies that the teachers created for curriculum are seen in Table IO. When these are examined, it is striking that they are rather different. Except for those, teachers likened curriculum to "manure of teaching" (P-6), "an elevator" (P-23), "sum of lessons and units" (P-32), "coal" (P-7), "A plane tree". These analogies, which display teachers' perceptions about curriculum, can also indicate that the curriculum is their mind is ambiguous. On this issue, in a study by Aykac \& Celik [17], it was seen that teachers likened curriculum to "defective, unused objects", "an object which seems good, but in fact hollow" and "limiting uniform rules" respectively. The reflections of the fact that curriculum is perceived as ambiguous on education are debatable, as it is not hard to foresee that teachers will do what s/he understands from curriculum. Because, it is known that teachers' beliefs affect their practices [22].

\section{RESULTS}

In the study, it was found out that the teachers' views about the meaning and definition of curriculum, which form the outer boundaries of it, are traditional. This is also the case for their views about the content of curriculum, which constitutes the inner boundaries of it. In teachers views on curriculum, no term about Information Age, or ICT was encountered except for a participant (P-22: Curriculum should be more innovative). So, it can be said that participants' perception of curriculum is traditional and far from integrity. Moreover, it was seen that teachers attribute various meanings to curriculum. These results indicate that curriculum in teachers' mind is rather dispersed. However, when we keep in mind that curriculum is very ambiguous and complex, this case is acceptable. Several possibilities of this can be mentioned. First, teachers are ineligible about curriculum literacy. Second, they do not understand curricula which have been prepared according to Information Age paradigms in Turkey (constructivism, postmodernism etc), since they were trained traditionally. Thirdly, they lack enough information about philosophy. Because, basis, purpose and all the other components of curriculum are philosophical [23].

Meaning crisis of curriculum, which teachers experience, has the potential to lead to problems in practice. However, this case can turn into an advantage in educational process which is suitable for Information Age paradigms, Because, teachers cannot be expected to be loyal to curriculum which they cannot make sense of. This case, which is a disadvantage in traditional approach, can turn into an advantage in constructivist educational approach. That is, not to be much dependent on curriculum provide an opportunity for teachers to use their own knowledge and capacity in favor of learners a lot more. Additionally, this case enables teachers to foresee what curriculum cannot, accordingly teaching becomes more humane. On this issue, Ornstein \& Hunkins's views [1] are striking: "The more the definition of curriculum is definite and people believe that it is finalized, the more they fail to notice learning and teaching-oriented socio-psychological factors (hard to observe)". More particularly, in countries like Turkey, where exams capture education and accordingly curriculum, considering socio-psychological factors can be seen as something relaxing humane attempts in class.

In the last instance, ironically, meaning crisis of curriculum can make teaching more active and humane in practice. Because, teaching in Information Age means providing chances to construct information, not to transfer it. So, it is an advantage that effect amount of curriculum for per students is low. This advantage counterbalances the disadvantage which is that the students are getting alike to one another because of dominant curriculum which is implemented by teachers. Finally, it should not be ignored that meaning crisis of curriculum can open new horizons for teachers about understanding of education and curriculum.

\section{REFERENCES}

[1] A. C. Ornstein and P. F. Hunkins, Eğitim Programı Temeller, Ilkeler ve Sorunlar, Konya: Eğitim Yayınevi, 2014.

[2] C. Karacaoğlu, Online Eğitimde Program Geliştirme, Ankara: İhtiyaç Yayınc1lik, 2011.

[3] H. Ünder et al., Eğitim ve Ahlak Şurası, Temmuz, Ankara, 2015.

[4] H. H. Özkan, "Bilgi toplumu eğitim programlari," Journal of Süleyman Demirel UniversityInstitue of Social Sciences, vol. 2, no. 10, pp. 13-132, 2009.

[5] G. DeLashmutt and R. Braund. (1996). Postmodernism and you: $\begin{array}{lll}\text { Education. } & \text { [Online]. Available: }\end{array}$ http://www.xenos.org/MINISTRIES/crossroads/OnlineJournal/issue2/ index.htm

[6] F. Arslan, Ilimler ve Ideolojiler, İstanbul: Umran Yayınları, 1971.

[7] S. R. Covey, 8'inci alişkanlik- bütünlüğedoğru(Çev: S. Soner ve Ç. Erendağ), İstanbul: SistemYayınclık, 2005.

[8] F. Varış, Eğitimde Program Geliştirme-teori, Teknikler, Ankara: Alkım Yayınları, 1996.

[9] J. Anyon. (2008). Schools as agencies of sciallegitimation. [Online] Available: http://weblogs.elearning.ubc.ca

[10] J. P. Clement. (1980). Parentse-ssentialto an effectiveCurriculum. [Online]. Available: http://bul.sagepub.com

[11] N. Fidan, Okulda Öğrenme ve Ögrretme, Ankara: Alkım Yayınları, 1996.

[12] A. Yıldırım and H. Şimşek, Sosyal Bilimlerde Nitel Araştırma Yöntemleri, Ankara: Seçkin Yayınları, 2003.

[13] N. Karasar, Bilimsel Araştırma Yöntemi, Ankara: Nobel Yayın Dağıtım, 1998.

[14] A. Balcı, Sosyal Bilimlerde Araştırma, Ankara: Pegem Akademi, 2009.

[15] S. Cepni, Araştırma ve Proje Çalışmalarına Giriş, Trabzon: Üçyol Kültür Merkezi Yayınları, 2005.

[16] Ş. Büyüköztürk, E. Kılıç, Ö. E. Akgün, Ş. Karadeniz, and F. Demirel Bilimsel Araştırma Yöntemleri, Ankara: Pegem A Yayınncılık, 2008.

[17] N. Aykaç and Ö. Çelik, "Öğretmenlerin ve öğretmen adaylarinin eğitim programina ilişkin metaforik algilarinin karşilaştirılması,' Eğitim ve Bilim, vol. 39, no. 173, pp. 328-340, 2014.

[18] Ministry of National Education. (2005). Milli Eğitim Bakanlığ [Online]. Available: http://www. meb.gov.tr

[19] A. Kesten and N. Özdemir, "Evaluation of social studies curriculum assessment part according to opinions of teachers: Case of Samsun," Firat University Journal of Social Science, vol. 20, no. 2, pp. 223-236, 2010.

[20] F. S. Kırmızı and N. Akkaya, "Türkçe öğretimi programinda yaşanan sorunlara ilişkin öğretmen görüşleri,” Pamukkale Üniversitesi Ĕ̌̆itim Fakültesi Dergisi, vol. 25, no.1, pp. 42-54, 2009.

[21] N. Akkuş, Yayımlanmamış Yüksek lisans Tezi, Ç. Ü. SBE, Eğitim Bilimleri Ana Bilim Dalı, 2007.

[22] Ş. Karakaya, Eğitimde Program Geliştirme Çalışmaları, Erzurum: Atatürk Üniversitesi Yayınları, 2001

[23] S. Ertürk, Eğitimde Program Geliştirme, Ankara: Meteksan Yayınları, 1998.

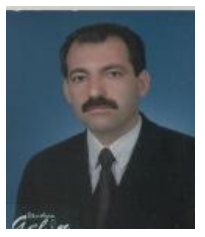

Burhan Akpinar was born in Elazı $\breve{g}$, Turkey, in 1962 He had B.A degree from Gazi University Dept. of Technical Education in Ankara in 1984. He had MsE degree from Inonu University in Malatya in 1992 and $\mathrm{PhD}$ degree from Inonu University in Malatya in 1998. Dr. Akpinar's major field of study is on curriculum and instruction, curriculum development in VTE, instruction 
and learning, philosophy of education, learning and senses and education technology.

He has completed many EU projects and instructed lots of master and $\mathrm{PhD}$ degree thesis. He had been an expert in Curriculum Development Studies for Ministry of National Education for two years. The writer has many national and international publications and published two course books (Curriculum Development in Education and Introduction to Education Sciences). He worked in Firat University Dept. of Education. He is working in Harran University Dept. of Education. He has many studies published in national/international indexed and peer-reviewed journals.
Veli Batdi had his B.A degree at Uludağ University Dept. of ELT Program in Bursa/Turkey. He had MsE and $\mathrm{PhD}$ degree from Firat University in Elazı $/ \mathrm{g} /$ Turkey. He works as an assistant professor at Kilis 7 Aralık University, Department of Curriculum and Instruction. His studies are especially related to teacher education, graduate education, English teaching/learning, curriculum evaluation. He makes use of many statistical programs such as meta-analysis, Rasch Measurement, NVIVO, Maxqda and SPSS programs. $\mathrm{He}$ has many articles published in national/international indexed and peer-reviewed journals. $\mathrm{He}$ is interested in using the underlying programs with the aim to studying on multi-analysis, multi-complementary approach. 